WellBeing International

WBI Studies Repository

8-1989

\title{
Lethargy and Low Water Intake by Sows During Early Lactation: A Cause of Low Piglet Weight Gains and Survival?
}

\author{
David Fraser \\ Agriculture Canada \\ P. A. Phillips \\ Agriculture Canada
}

Follow this and additional works at: https://www.wellbeingintlstudiesrepository.org/farahus

Part of the Agribusiness Commons, Animal Studies Commons, and the Operations and Supply Chain Management Commons

\section{Recommended Citation}

Fraser, D., \& Phillips, P. A. (1989). Lethargy and low water intake by sows during early lactation: A cause of low piglet weight gains and survival?. Applied Animal Behaviour Science, 24(1), 13-22.

This material is brought to you for free and open access by WellBeing International. It has been accepted for inclusion by an authorized administrator of the WBI Studies Repository. For more information, please contact wbisr-info@wellbeingintl.org.

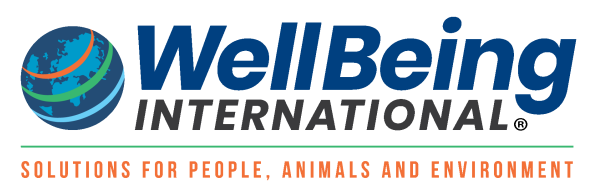




\title{
Lethargy and Low Water Intake by Sows During Early Lactation: A Cause of Low Piglet Weight Gains and Survival?
}

\author{
David Fraser and P.A. Phillips \\ Agriculture Canada
}

\begin{abstract}
Daily water intake was monitored for 40 sows during 5 days before and 14 days after farrowing. Intake averaged 9-12 I day ${ }^{-1}$ before farrowing, dropped to a mean of 6 I on the day of farrowing and increased gradually over 4 days to a plateau of $\sim 14$ I day ${ }^{-1}$. Sows varied greatly in the degree of reduction in intake during the day of farrowing and the first 3 days of lactation, and those sows with low water intake on these days had low average weight gains by the piglets in the same period. Most of the piglet deaths in the study (14 of 19) occurred in the 10 litters whose dam consumed $\leq 6$ I day ${ }^{-1}$ of water from Day 0 to 3 of lactation. Monitoring of 14 sows by time-lapse video recording showed that gross physical activity (percentage of time standing and sitting) varied greatly among sows during the first 3 days after farrowing, with the less active sows having significantly lower water intake. We suggest that some sows are excessively lethargic in the first days after farrowing and fail to consume adequate water, and that this could contribute to low milk production in early lactation.
\end{abstract}

\section{INTRODUCTION}

Many sows evidence some degree of depressed milk production (hypogalactia) during the first days after farrowing (Martin and McDowell, 1975). A host of factors is thought to contribute to the problem. These include bacterial infection of the udder (e.g., Ross et al., 1981), metabolic disturbances resulting in low blood glucose levels (e.g., Ringarp, 1960), hormonal imbalances (Gooneratne et al., 1982), high ambient temperatures (Fraser, 1970), and various features of management and nutrition (Bäckström et al., 1984, reviewed by Martin and McDowell, 1975).

In certain cases, low milk production in early lactation has been attributed to inadequate water intake by sows, especially if drinking requires appreciable effort to operate a nipple drinker (e.g., Anon., 1987). In such cases, the relative inactivity of sows in early lactation could compound the problem.

In this study, we monitored early piglet weight gains (as an approximate index of early milk production), sow water intake, and sow activity. Our objec-tives were: (1) to quantify sow water intake during the days before and after farrowing; (2) to determine whether sows with low water intake in the first days after farrowing would tend to have poor piglet weight gains in this period; (3) to determine whether low water intake is associated with low general ac-tivity in the postpartum sow. 


\section{MATERIALS AND METHODS}

Water intake was monitored for 40 Yorkshire sows from the Animal Re-search Centre's specificpathogen-free herd. Sows were housed in farrowing crates installed in farrowing pens of 3.5-3.9 $\mathrm{m}^{2}$ with plastic-coated, expanded metal flooring raised $0.3 \mathrm{~m}$ above the floor of the room. Each pen was equipped with a heat lamp and a plastic water dispenser for the piglets in the creep area. Ambient temperature in the room was generally kept at $20-24^{\circ} \mathrm{C}$ by use of supplementary heating and cooling equipment, but extremes of 15 and $29^{\circ} \mathrm{C}$ were recorded. Four different farrowing crate designs, described by Fraser et al. (1988), were used in the study.

Sows were moved into the crates 5 days before farrowing was due. Pelleted feed was provided at $2 \mathrm{~kg}$ $\mathrm{day}^{-1}$ before farrowing and ad libitum thereafter, with the feed trough refilled daily. Sows had continuous access to water from a nipple drinker (Model BND, Bauman Mfg., Wallenstein, Ontario) installed $0.6 \mathrm{~m}$ above the floor. Routine management of the piglets included ear notching for identification and clipping the needle teeth on the first day after birth, iron injection on Days 3 and 10, and castration of males on Day 10. Sows and litters remained in the crates until the piglets were 14 days old. The rectal temperature of each sow was recorded twice daily (at 10.00-12.00 and 15.00-16.00 h) during the first 5 days after farrowing.

Sow water intake was determined during the 5 days before and 14 days after farrowing using methods described by Phillips and Leclerc (1986). Briefly, each nipple drinker was fed by a small pressurized tank which was automatically refilled by the barn water system each time the tank pressure dropped below a set point. An electronic data logger recorded the time of each refilling of the tank. The pressure set-points were adjusted to deliver $\sim 1$ I of water between each refilling of the tank and the calibration was checked daily. Metal trays, $65 \times 91 \times 10 \mathrm{~cm}$ deep and capable of holding $\sim 60$ I of water, were in-stalled beneath the raised floor of the farrowing pens to collect spillage. The water in the trays was removed and weighed each day between 10.00 and $12.00 \mathrm{~h}$. A small allowance was made for evaporation from the spillage trays; this was usually $0.8 \mathrm{I}$ day $^{-1}$, or less if the floor of the tray was not completely covered by water. The nipple drinkers delivered $\sim 0.71 \mathrm{~min}^{-1}$ when fully open. Of the 760 records (40 sows $\times 19$ days), 21 could not be used because of technical problems with the recording equipment.

Piglets were weighed to the nearest $5 \mathrm{~g}$ on the first morning after farrowing was complete, on each of the next four mornings, and on Days 7, 10 and 14 after birth. All weighing was carried out between 10.00 and $12.00 \mathrm{~h}$ so that daily weight gains would cover a period close to $24 \mathrm{~h}$. However, this meant that some litters were nearly $24 \mathrm{~h}$ old when weighed for the first time. To determine if there were any differences arising from age at first weighing, we noted whether a litter farrowed before or after $16.00 \mathrm{~h}$ each day, this being the last time during the day that sows were routinely checked. This divided the litters into two age classes (0-18 $\mathrm{h}$ versus 18-24 h) at the time of first weighing. To minimize the effects of different litter sizes, all litters were adjusted to 10-12 piglets, as de-scribed by Thompson and Fraser (1988). Three of the 40 litters were omitted from analysis because of incomplete weight data or because suitable piglets were not available for fostering.

In comparing sow water intake with piglet weight gain, we considered each day as starting at noon since both piglet weights and water spillage were de-termined between 10.00 and $12.00 \mathrm{~h}$. Day 0 was defined as the 24-h period (from noon to noon) during which farrowing began; hence, the piglets were first weighed at the beginning of Day 1.

Gross physical activity was monitored for 14 sows, chosen according to convenience. Each of these sows was filmed for several days before and after farrowing by use of a time-lapse video recorder (Model TC3920, RCA Closed Circuit Video Equipment, Lancaster, PA) triggered by a programmable clock 
(Chrontrol Model CD, Lindburg Enterprises, San Diego, CA) to record one field per minute. The sow's posture in each field was later classified as standing (supported on all four legs), sitting (supported on the front legs and hind quarters) or lying. The percentage of fields in which the sow was standing or sitting was used as a measure of gross physical activity. Since the activity and water intake data were available on an hourly basis, it was possible to organize these data more precisely around the time of farrowing. Both measures were therefore calculated for 4 days comprising the 24-h period which ended with the hour when farrowing began and the first $72 \mathrm{~h}$ after the beginning of farrowing.

For statistical analysis, the mean weight gain of each litter was calculated for each of the first 4 days after farrowing as the mean of the individual weight gains for all piglets surviving the relevant day. Average litter gain over the first 3 days was used as a convenient measure of early weight gain, as suggested by Thompson and Fraser (1988). These 3-day litter gains were compared with sow water intake in early lactation using Pearson correlations based on the 34 sows with complete data on water intake and piglet weight gains on all the relevant days. Correlations were also calculated for various sub-sets of the data (with data divided according to farrowing crate type, sow parity number, litter size and litter age class at first weighing) to ensure that the overall correlation was not unduly influenced by specific sub-sets.

\section{RESULTS}

\section{Sow water intake}

Daily water intake by the 40 sows averaged $\sim 9$ I day ${ }^{-1}$ during the 3-5 days before farrowing and increased on the day immediately before farrowing. Intake dropped to an average of $\sim 61$ on the day of farrowing, and then increased gradually to an average of $\sim 141$ day $^{-1}$ on the fourth and subsequent days after parturition (Fig. 1). The reduction of water intake during and after farrowing was very pronounced for some sows, but not for others. Values for individual sows ranged from 4 to $11 \mathrm{I} \mathrm{day}^{-1}$, averaged over days $0-3$.

As the lactation advanced, the sows established fairly consistent individual differences in water intake. For example, individual water intake on Days 4-6 after farrowing was highly correlated with intake during the second week $(r=0.846)$. However, water intake during the first 2 days after farrowing was less correlated with later intake ( $r=0.438$ with intake on Days 4-6; $r=0.326$ with intake on Days 7-13) and showed no correlation with intake during the 5 days before farrowing began $(r=0.04)$. The highest body temperature recorded for each sow on Days 0-3 was weakly correlated with water intake on Days 0 and 1 $(r=-0.34)$, but not with water intake later in lactation.

\section{Piglet weight gains and survival in relation to sow water intake}

There were large differences between litters in average weight gain during the first few days after farrowing (Table 1). Piglet weight gain on the first 3 days was significantly correlated with sow water intake during the same 3-day period $(r=0.49)$ and the correlation improved slightly if sow water intake on the day of farrowing was also included ( $r=0.53$, Fig. 2). This correlation in-cluded one outlying litter (Litter 59) whose dam drank far more water than the others (Fig. 2). With this litter omitted, the correlation rose to $r=0.68(P<0.001)$. The correlations were similar regardless of whether the 8 sows with high body temperature $\left(>40.6^{\circ} \mathrm{C}\right.$ ) were included in the analysis (Fig. 2). Correlations based on different sub-sets of the data, calculated for the two age classes of piglets (0-18 and 18-24 hat first weighing), the four farrowing crate types, and the different litter sizes and sow parity numbers, gave similar correlation coefficients. Gain in the first 3 days was less closely correlated with the sow's maximum body temperature $(r=-0.35)$ and with the average weight of the litter at first weighing $(r=0.27)$. Sow water intake on Days 0-3 was only weakly correlated with the average birth weight of the piglets $(r=0.31, P<$ 
0.10 ) and tended to decline slightly with increasing litter size (mean \pm s.e. of $8.4 \pm 0.5$ I day $^{-1}$ with litters of 10 pigs, $7.4 \pm 0.9$ with 11 and $6.6 \pm 1.0$ with 12 ).

Fig. 1. Daily water intake by sows 5 days before and 14 days after farrowing. Vertical bars enclose the 10th and 90th percentile values, with means shown by the filled circles. Day 0 is the day (noon to noon) on which farrowing began.

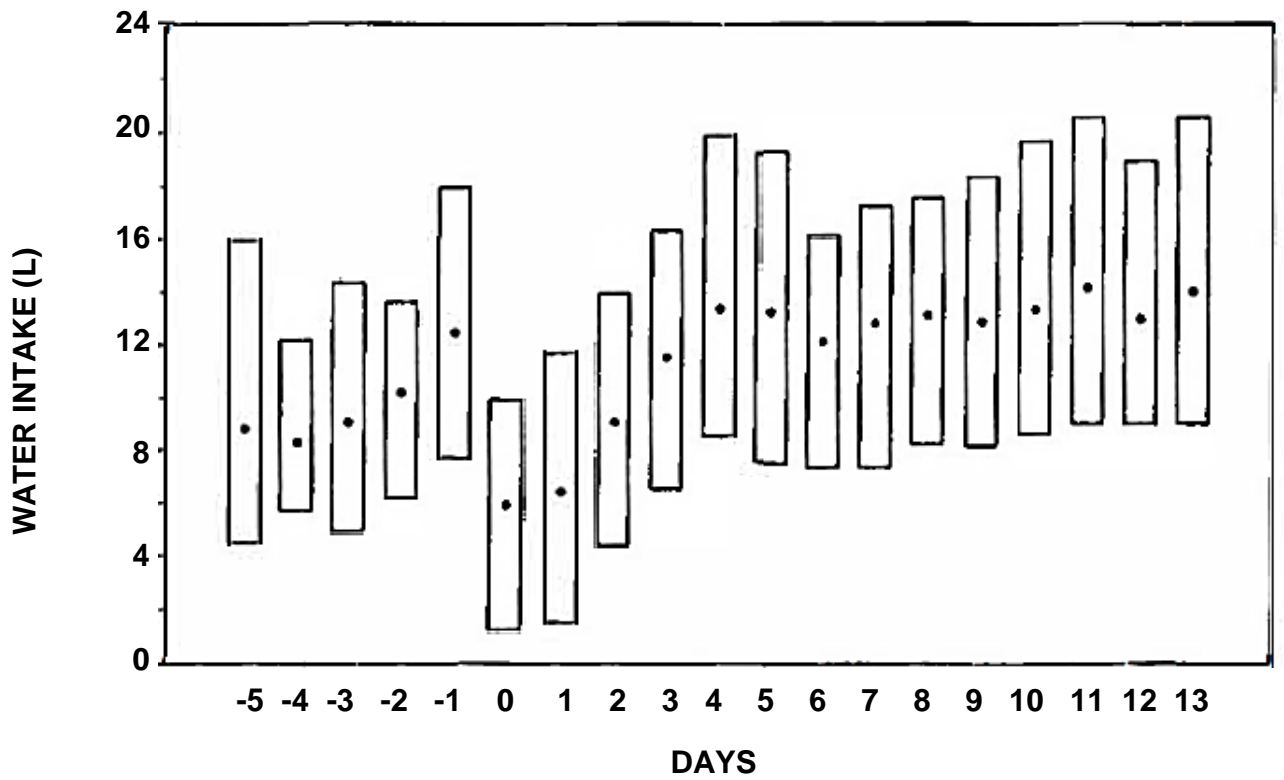

TABLE 1. Weight gains ( mean, S.D., minimum and maximum of litter means) of the 37 litters of piglets during the first 4 days after farrowing

\begin{tabular}{|ccccc|}
\hline Day & Mean (g per piglet) & S.D. & Minimum (g per piglet) & Maximum (g per piglet) \\
\hline 1 & 88 & 67 & -51 & 224 \\
2 & 135 & 47 & 4 & 221 \\
3 & 153 & 43 & 51 & 236 \\
4 & 172 & 42 & 48 & 283 \\
\hline
\end{tabular}

In the 37 litters with complete piglet data, 19 piglets died in the 14-day period beginning when the litter was first weighed. Fourteen deaths $\left(12.6 \%\right.$ mortality) occurred in the 10 litters with the lowest $\left(\leq 6\right.$ I day $\left.{ }^{-1}\right)$ sow water intake on Days 0-3. These involved 5 litters with deaths $(7,3,2,1$ and 1 death per litter) and 5 without. Only five deaths (1.8\% mortality) occurred in the remaining 27 litters. These involved 5 litters with one death each and 22 litters without deaths.

\section{Sow activity and water intake}

The 14 sows studied by time-lapse video recording were active (standing or sitting) for an average of $30.5 \%$ of the $24-\mathrm{h}$ period immediately before farrowing (Table 2). Active time dropped to $5.1 \%$ in the $24 \mathrm{~h}$ during and after farrowing, and increased gradually over the next 2 days (Table 2). Average water intake followed a similar pattern (Table 2). The sows' individual water intake and activity measures were correlated on each of the days (Table 2) and over the 72-h period after farrowing (Fig. 3: $r=0.73, P<$ 0.01 with Litter59 omitted). 
Fig. 2. Relationship between average piglet weight gain $\left(g\right.$ day $\left.^{-1}\right)$ during the first 3 days after birth and average sow water intake (I day- 1) on the same 3 days plus the day of farrowing. Each point represents one of the 34 litters with complete records of both weight gain and water intake. Sows with a maximum body temperature of $>40.6^{\circ} \mathrm{C}\left(>105^{\circ} \mathrm{F}\right)$ are shown by open circles. The correlation is $r=0.53$ based on all data, $r=$ 0.68 omitting Litter 59 (the outlier at the right) and $r=0.65$ omitting the outlier and sows with high body temperature.

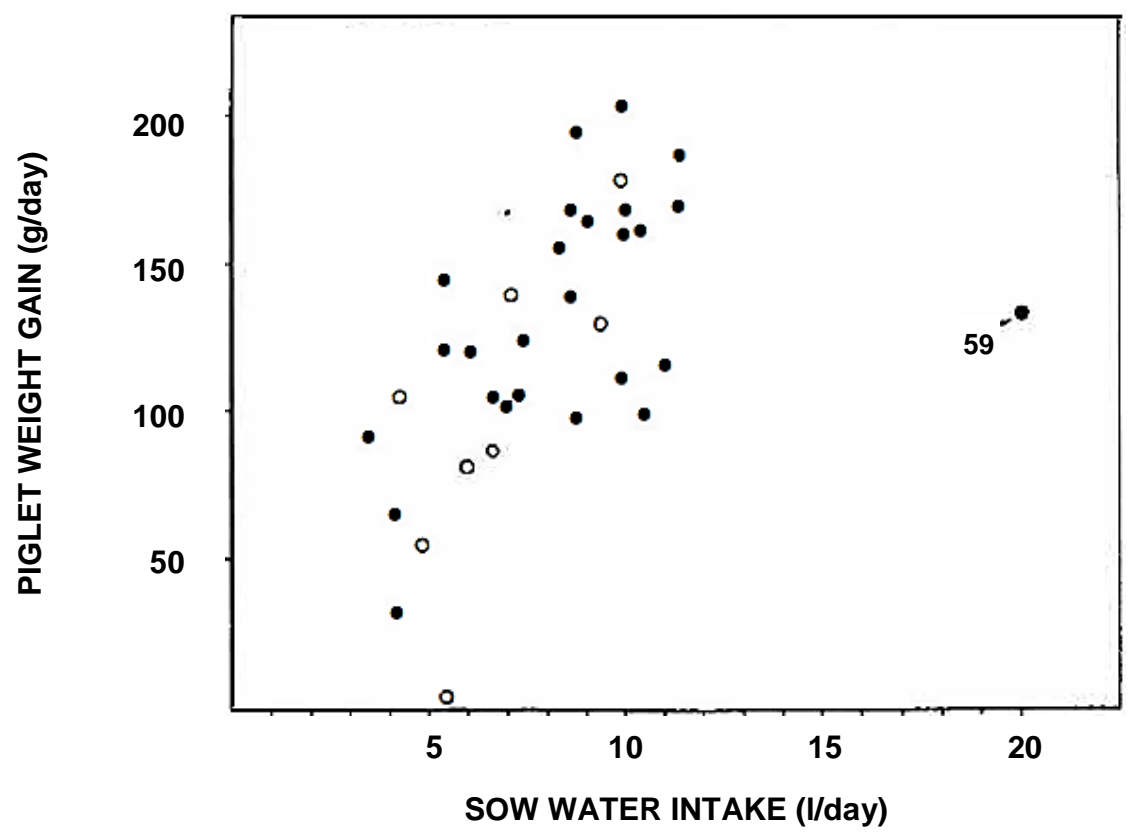

Fig. 3. Relationship between water intake $\left(\mathrm{I} \mathrm{day}^{-1}\right)$ and the percentage of time spent active (standing or sitting) by sows during the first $72 \mathrm{~h}$ after the beginning of farrowing.

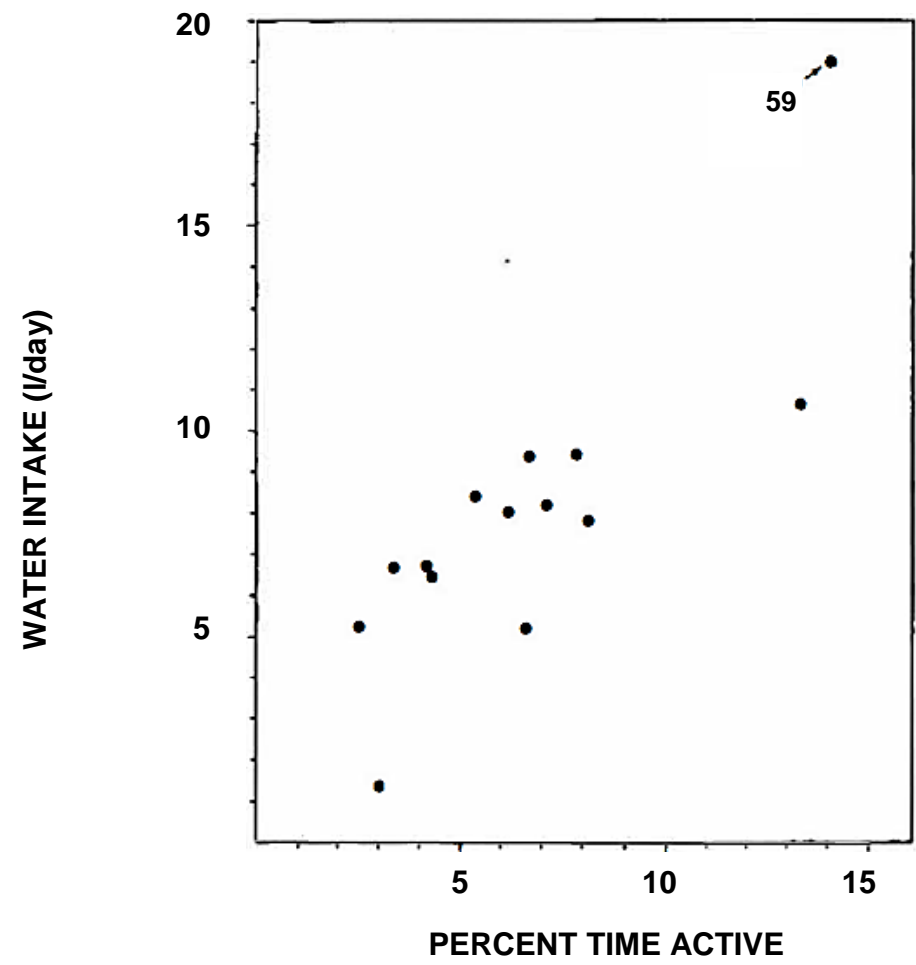


TABLE 2. Percentage of time spent active (standing and sitting combined) and water intake of the 14 sows recorded by time-lapse video recording during the $24 \mathrm{~h}$ before and the $72 \mathrm{~h}$ after the start of farrowing

\begin{tabular}{|c|c|c|c|}
\hline Time relative for farrowing & $\begin{array}{l}\text { Percent time active } \\
\text { (mean and range) }\end{array}$ & $\begin{array}{l}\text { Water intake }(\mathrm{I}) \\
\text { (mean and range) }\end{array}$ & $r^{a}$ \\
\hline $24 \mathrm{~h}$ before & $30.5(22.4-42.8)$ & $12.8(5.6-24.1)$ & 0.63 \\
\hline 1-24 $h$ after & $5.1(1.5-14.9)$ & $4.9(0.0-15.7)$ & 0.71 \\
\hline 25-48 h after & $6.5(1.8-15.3)$ & $8.4(1.0-21.2)$ & 0.92 \\
\hline 49-72 h after & $8.2(2.7-15.3)$ & $10.9(3.2-20.0)$ & 0.58 \\
\hline
\end{tabular}

${ }^{a}$ Correlation between percent time active and water intake based on $n=14$ sows. Critical values, two-tailed, are $r=0.53(P<0.05), r=0.66(P<0.01)$ and $r=0.78(P<0.001)$.

\section{DISCUSSION}

Litter weight gain in the first 3 days after birth is an important variable in piglet production. Litters with low gains during this early period tend to have considerably lower rates of survival (de Passillé, 1987) as well as lower and more variable weight gains later in lactation (Thompson and Fraser, 1988).

In this study, early piglet weight gains were clearly correlated with the sow's water intake during the same period, and water intake was in turn correlated with the sow's degree of physical activity. These correlations need to be interpreted with great care.

One possible explanation would be that a low demand for milk by a small or weak litter stimulated a low level of milk production and a correspondingly low water intake by the sow. This is unlikely because sow water intake in early lactation was correlated only weakly with the average birth weight of the litter $(r=$ 0.31 ) and actually tended to be lower in litters with the greatest number of piglets. Furthermore, the sows whose piglets gained poorly drank less in early lactation than they had done before farrowing.

A second possibility is that some sows in early lactation contract an infectious disease which causes reduced milk production, reduced physical activity and reduced intake of water (and probably of feed). According to this interpretation, reduced water intake might be a symptom of illness, but not a direct cause of low milk production. This interpretation may well apply in some cases of the mastitis-metritisagalactia syndrome. However, in our study, carried out using a specific-pathogen-free herd, there was no clear distinction between sick and healthy sows, and no instances of the excessively firm, discoloured mammary glands that are often associated with mastitis. Furthermore, the correlation between sow water intake and piglet weight gain remained clear even after sows with high body temperature had been omitted (Fig. 2).

The third possibility, which we think merits the most attention, is that the low water intake of some sows actually contributed to inferior milk production and a resulting poor performance by their piglets. Physiological work would be needed to determine the actual water requirement for early lactation, but we suspect that the sows with the lowest water intakes were not drinking enough.

A reduction in food intake is commonly seen in sows during and just after farrowing. Some reduction in activity and water intake is probably normal as well. In a more natural environment, sows generally do not leave the nest during the first day after farrowing (Jensen, 1986) and they presumably do not eat or drink during this time. The relative inactivity of the farrowing sow is arguably an adaptive component of maternal behaviour. By lying quietly, the farrowing sow minimizes the risk of trampling or crushing the newborns and allows the piglets to have uninterrupted access to the udder for ingestion of colostrum, for warmth and to begin the learning process associated with the development of suckling behaviour (Hurnik, 
1985). However, in domesticated animals bred for docility, the natural postpartum inactivity may be excessive in some individuals owing, perhaps, to genetic, hormonal or other differences.

It is not clear why very low water intake is associated with this excessive inactivity. If drinking requires a sow to stand and operate a slow-flowing nipple drinker, then the more lethargic animals may simply not persist enough to achieve an optimum water intake. Alternatively, since pigs consume much of their water in the course of eating (e.g., Bigelow and Houpt, 1988), a lack of interest in food might deprive the sow of a principal stimulus to drink.

A note of caution arises from the large discrepancies in the water intake of lactating sows reported in various studies. Our values, averaging $\sim 14 \mathrm{I} \mathrm{day}^{-1}$ from Day 4 to 14 of lactation, are similar to the values of $\sim 11-14$ I day ${ }^{-1}$ reported by Diblík (1986), but contrast with the previously reported values of 8 I day $^{-1}$ (Friend, 1971), $18 \mathrm{I} \mathrm{day}^{-1}$ (Lightfoot, 1978; Lightfoot and Armsby, 1984), $20 \mathrm{I} \mathrm{day}^{-1}$ (Bauer, 1982) and $25 \mathrm{I}$ day $^{-1}$ (Riley, 1978). Evidently, sow water intake varies greatly, depending on conditions yet to be determined. This variation needs to be better understood.

\section{ACKNOWLEDGEMENTS}

We are grateful to Mr. N. Breedyk, supervisor of the ARC pig unit, for focusing our attention on sow water intake, to Ms. W.B. Peeters Weem, Mr. R.A. Arcand and the staff of the ARC pig unit who kindly participated in the data collection, and to Drs. L. Ainsworth and J.N.B. Shrestha for their comments on the manuscript.

\section{REFERENCES}

Anonymous, 1987. Dead pigs by the bucketfuls. Nat. Hog Farmer, 32: 32-39.

Bäckström, L., Morkoc, A.C., Connor, J., Larson, R. and Price, W., 1984. Clinical study of mastitismetritis-agalactia in sows in Illinois. J. Am. Vet. Med. Assoc., 185: 70-73.

Bauer, W., 1982. Der Trankwasserverbrauch guster, hochtragender und lactierender Jungsauen. Arch. Exp. Veterinarmed., Leipzig, 36: 823-827.

Bigelow, J.A. and Houpt, T.R., 1988. Feeding and drinking patterns in young pigs. Physiol. Behav., 43: 99-109.

De Passillé, A.M.B., 1987. Suckling and related behaviour of piglets: Ontogeny and implications for production. Ph.D. Thesis, McGill University, Montreal.

Diblík, T., 1986. Vliv typu napájecek na mnozstiví vody prijaté prasnicemi. Zivocisna Yýroba, 31: 10291036.

Fraser, A.F., 1970. Field observations in Jamaica on thermal agalactia in the sow. Trop. Anim. Health Prod., 2: 175-181.

Fraser, D., Phillips, P.A. and Thompson, B.K., 1988. Initial test of a farrowing crate with inward-sloping sides. Livest. Prod. Sci., 20: 249-256.

Friend, D.W., 1971. Self selection of feeds and water by swine during pregnancy and lactation. J. Anim. Sci., 32: 658-666. 
Gooneratne, A.D., Hartmann, P.E. and Nottage, H.M., 1982. The initiation of lactation in sows and the mastitis-metritis-agalactia syndrome. Anim. Reprod. Sci., 5: 135-140.

Hurnik, J.F., 1985. A review of periparturient behavior in swine. Can. J. Anim. Sci., 65: 777-788.

Jensen, P., 1986. Observations on the maternal behaviour of free-ranging domestic pigs. Appl. Anim. Behav. Sci., 16: 131-142.

Lightfoot, A.L, 1978. Water consumption of lactating sows. Anim. Prod., 26: 386 (Abstract).

Lightfoot, A.L. and Armsby, A.W., 1984. Water consumption and slurry production of dry and lactating sows. Anim. Prod., 38: 541 (Abstract).

Martin, C.E. and McDowell, W.S., 1975. Lactation failure (mastitis-metritis-agalactia). In: H.W. Dunne and A.O. Leman (Editors), Diseases of Swine, 4th edn. lowa State University Press, Ames, IA, pp. 953-960.

Phillips, P.A. and Leclerc, J.M., 1986. Sensor for monitoring sow drinking. Appl. Eng. Agric., 2: 158-160.

Riley, J.E., 1978. Drinking straws. A method of watering housed sows during pregnancy and lactation. Anim. Prod., 26: 386 (Abstract).

Ringarp, N., 1960. Clinical and experimental investigation into a post-parturient syndrome with agalactia in sows. Acta Agric. Scand., Suppl. 7.

Ross, R.F., Orning, A.P., Woods, R.D., Zimmerman, B.J., Cox, D.F. and Harris, D.L., 1981. Bacteriologic study of sow agalactia. Am. J. Vet. Res., 42: 949-955.

Thompson, B.K. and Fraser, D., 1988. Variation in piglet weights: Weight gains in the first days after birth and their relationship with later performance. Can. J. Anim. Sci., 68: 581-590. 